\title{
Sulisława Borowska
}

https://orcid.org/0000-0003-0110-2095

Kaszubski Uniwersytet Ludowy

\section{Marek Byczkowski}

https://orcid.org/0000-0003-1719-780X

Kaszubski Uniwersytet Ludowy

\section{Tomasz Maliszewski}

https://orcid.org/0000-0002-8366-7614

Akademia Marynarki Wojennej w Gdyni

Mariusz Mówka

https://orcid.org/0000-0003-0811-8946

Kaszubski Uniwersytet Ludowy

\section{Kaszubski Uniwersytet Ludowy w XXI stuleciu - ciągłość i zmiana}

\author{
Kashubian Folk High School in 21st Century - \\ Continuity and Change
}

Streszczenie. Artykuł stanowi próbę częściowego podsumowania ostatnich dwóch dekad funkcjonowania Kaszubskiego Uniwersytetu Ludowego (KUL) w Wieżycy koło Szymbarku. Czteroosobowy zespół autorski, związany z tą placówką pozaformalnej edukacji dorosłych, stara się wyłowić z bogatej i wielowątkowej działalności tej instytucji te komponenty, które występują w niej w sposób ciągły w całym okresie XXI wieku, stanowiąc de facto o jej tożsamości. Do takich aspektów „długiego trwania” zaliczają oni: podstawy ideowe i aksjologiczne, bazę, środowisko lokalne i region, elementy metodyczno-programowe zarówno te grundtvigiańskie - wypracowane w łonie wszystkich uniwersytetów ludowych (UL) na bazie koncepcji „szkoły dla życia”, jak i te swoiste, właściwe własnemu środowisku edukacyjnemu - wypracowane na bazie kumulowania własnych doświadczeń w tym zakresie, współpracę międzynarodową itp.

Autorzy ukazują też podstawowe kierunki zmian, jakich Kaszubski Uniwersytet Ludowy doświadczył w latach 2001-2020. Związane one były z nowymi wyzwaniami społecznymi, politycznymi i gospodarczymi, na które należało szybko odpowiedzieć skuteczną ofertą edukacyjną wychodzącą naprzeciw oczekiwaniom otoczenia społecznego placówki, ale też ze zmianą stosunków własnościowych i sytuacji prawnej KUL-u. Niewątpliwie istotną zmianą 
było pojawienie się 1 stycznia 2018 roku w przedstawianej w szkicu placówce nowego lidera i wiążące się z tym pewne przemodelowanie wizji jej funkcjonowania w przyszłości.

Z artykułu wyłania się obraz Kaszubskiego Uniwersytetu Ludowego jako wartościowego podmiotu pozaformalnej edukacji dorosłych, aktywnie i skutecznie działającego na rzecz edukacyjnego wsparcia i rozwoju społeczności wiejskich (i małomiasteczkowych) Kaszub i Pomorza. Przez lata zdobył on uznanie dalece wykraczające poza region, w którym prowadzi swoją działalność.

Słowa kluczowe: Kaszubski Uniwersytet Ludowy; pozaformalna edukacja dorosłych; uniwersytety ludowe; edukacja regionalna; edukacja obywatelska

Summary. The article is an attempt to partially summarize the last two decades of functioning of the Kashubian Folk High School (KFHS) in Wieżyca near Szymbark. The four person author team connected with this non-formal adult education institution tries to pick up from the rich and multi-topic activity of this institution the components that have always been present there in the 21st century, which, de facto, constitutes it identity. These aspects of "lasting duration" include: ideological and axiological foundations, base, local and regional environment, methodological-program elements, both the Grundtvigian ones developed by all folk high schools (FHS) on the basis of the concept of "school for life", and the individual ones developed for an individual educational environment - developed based on accumulated experience in this area, including international cooperation, etc.

The authors also show the basic directions of changes that the Kashubian Folk High School experiences during the period of 2001-2020. They were connected with new social, political and economic challenges that should be quickly faced with an effective educational offer meeting the expectations of the social environment of the institution, but also with the changes of ownership and legal situation of KFHS. Undoubtedly, a significant change was the emergence of a new leader in the educational institution presented in the sketch of the 1st of January 2018 and connected with it a certain remodeling of the vision of its functioning in the future.

The article draws a picture of Kashubian Folk High School as a valuable entity of nonformal adult education institution, actively and effectively acting for educational support and development of rural (and small town) communities of Kashubian and Pomeranian regions, which has also gained recognition over the years that goes well beyond the region in which it operates.

Keywords: Kashubian Folk High School; non-formal adult education; folk high schools; regional education; civic education. 
Marka to żyjąca pamięć Jean-Noel Kapferer, 1995

\section{Wprowadzenie}

Na wstępie rozważań warto podkreślić, że niniejsze opracowanie nie pretenduje do całościowego, monograficznego zaprezentowania dziejów Kaszubskiego Uniwersytetu Ludowego w Wieżycy (KUL) w okresie XXI stulecia. Na tak obszerne, kompleksowe ujęcie wszystkich sfer i obszarów działalności tej placówki oświatowej przyjdzie zapewne czas w niedalekiej przyszłości. Autorzy stawiają sobie dużo skromniejsze cele, odnoszące się jedynie do ukazania niektórych obszarów pracy KUL-u w ostatnim dwudziestoleciu, takich jak:

- ukazanie związków placówki ze skandynawskimi korzeniami ruchu uniwersytetów ludowych (UL);

- zaprezentowanie kilku najważniejszych aspektów funkcjonowania tego zakładu oświatowego w XXI wieku do chwili przejścia na emeryturę twórcy i długoletniego lidera kaszubskiego UL-u;

- wskazanie głównych kierunków działalności i niektórych bardziej szczegółowych zadań podejmowanych przez wieżycki uniwersytet pod kierunkiem jego następcy;

- sformułowanie konkluzji, dotyczących funkcjonowania KUL-u w bieżącym stuleciu z odniesieniem do zadań i działań czekających tę instytucję w przyszłości.

Niniejszy szkic został przygotowany przez czteroosobowy zespół autorski składający się z trojga praktyków i teoretyka - badacza. Zawiera więc zarówno elementy sprawozdawcze i refleksje osób bezpośrednio i na co dzień związanych z działaniami pojmowanymi przez Kaszubski Uniwersytet Ludowy na przestrzeni ostatnich dwóch dekad, jak również próby pewnego zsyntetyzowania i uogólnienia poszczególnych wątków zaproponowane przez czwartego z autorów*.

* Autorom wypada wyrazić nadzieję, że Czytelnicy taki częściowo sprawozdawczy, częściowo naukowy charakter opracowania uznają za walor, nie zaś za usterkę tego artykułu. 
Merytoryczną część szkicu zacząć należy od wyjaśnienia, dlaczego autorzy wybrali dlań takie właśnie motto, jakie odnotowano wyżej? Otóż Kaszubski Uniwersytet Ludowy, któremu poświęcono to opracowanie, działa już od niemal czterech dekad. Oznacza to, że przynajmniej dwa pokolenia słuchaczy, wykładowców z Kaszub, Pomorza i szerzej - z Polski i zagranicy, miało okazję w ten czy inny sposób zetknąć się z placówką. Dla wielu z tych osób wspomnienia i doświadczenia zdobyte w KUL-u są nadal ważne, i to nie tylko ze względu na zdobytą wiedzę czy umiejętności. Okazuje się, że po latach ważne pozostaje również wspomnienie dobrego miejsca, czyli pamięć o dobrych emocjach i odczuciach związanych z pobytem (por. np. Borowska, Maliszewski, 2017; Mówka, 2020).

Dyskusje o misji placówki, o wyborze kierunków rozwoju, o sposobie operacjonalizacji celów, jakie przez cały wiek XXI (i wcześniej) były prowadzone w kaszubskim UL-u, zawsze docierały do punktu, w którym mowa o prowadzeniu czy organizowaniu czegoś „jak w KUL-u”, o „atmosferze KUL-u”, o traktowaniu słuchaczy „jak w KUL-u”. Taka zauważalna niedookreśloność, ale i jednoznacznie pozytywny charakter wspomnień, pojawiających się u wszystkich mających przez lata styczność z wieżyckim uniwersytetem, nasuwają nieodparte skojarzenia $\mathrm{z}$ marketingowym pojęciem marki.

Ściśle sprzężona z marką pozostaje swoista pamięć instytucjonalna właściwa KUL-owskiej społeczności. To bowiem ludzie, którzy tworzyli i rozwijali tę instytucję, oraz budowana przez lata ekspercka sieć wsparcia tworzą najcenniejszy zasób, który można by określić mianem kapitału instytucji.

Z powyższych uwag jednoznacznie wynika, że niewątpliwie „mamy do czynienia z dwoma rodzajami »żyjącej" pamięci Kaszubskiego Uniwersytetu Ludowego: pamięci odbiorców jego działań i pamięci organizacji, przechowanej u kluczowych pracowników" (Mówka 2020). Tak więc zaczerpnięte z Jeana-Noela Kapferera motto wydaje się mieć w przypadku artykułu dotyczącego KUL-u pełne uzasadnienie.

\section{Skandynawskie korzenie Kaszubskiego Uniwersytetu Ludowego}

Charakterystykę działalności Kaszubskiego Uniwersytetu Ludowego w bieżącym stuleciu należy rozpocząć od przywołania przynajmniej kilku kwestii 
ideowych oraz potencjalnych potrzeb edukacyjnych środowiska wiejskiego, w którym i na rzecz którego placówka działa.

Odnosząc się zagadnienia idei, warto przypomnieć, że internatowe uniwersytety ludowe - w tym kaszubski - mają swoje korzenie w Skandynawii. Z faktu tego wynika ich głębokie przywiązanie do Grundtvigiańskich idei szkoły dla życia (skole for livet) i wyższej szkoły ludowej (folkehøjskole) oraz inspirowanie się treściami programowymi i metodami pracy wypracowanymi w krajach nordyckich - zwłaszcza w Danii (por. np. Byczkowski, Maliszewski, Przybylska (red.) 2003; Maliszewski (red.) 2016).

W Kaszubskim Uniwersytecie Ludowym szczególnie cenione są refleksje Karla Kristiana Ægidiusa - wieloletniego profesora Wolnej Szkoły Nauczycielskiej w Ollerup (Den Frie Lœererskole i Ollerup), przygotowującej kadry do pracy pedagogicznej w duńskich folkehøjskoler i innych placówkach oświaty niezależnej. Przez trzy ostatnie dekady był on bowiem swoistym mentorem dla całej społeczności KUL-u. Warto zatem poświęcić nieco więcej uwagi jego opiniom, gdyż niewątpliwie dały one podwaliny pod sposób formułowania własnych założeń ideowych przez środowisko placówki w bieżącym stuleciu (Byczkowska, Maliszewski 2003, s. 177-185).

I tak ten „wielki przyjaciel Wieżycy” podczas jednego z międzynarodowych seminariów zorganizowanych przez KUL w chwili, gdy zaledwie rok dzielił Polskę od przystąpienia do Unii Europejskiej, sformułował myśl, zgodnie z którą

najważniejszymi aktualnymi zadaniami i wyzwaniami dla Polski są rozwój demokracji oraz rozwój gospodarki rynkowej. Co prawda, demokrację i gospodarkę rynkową oficjalnie wprowadzono w Polsce ustanowionym prawem i stały się one komponentami polskiej rzeczywistości, nie da się jednak jednocześnie powiedzieć, że funkcjonują one optymalnie i dają obywatelom satysfakcję. [...] To dlatego należałoby zapytać: co mogliby zrobić zwykli obywatele, aby przyczynić się do ich lepszego funkcjonowania? (Arch-KUL, 2003).

\section{I kontynuował:}

Gdy jako Duńczyk patrzę wstecz na ten okres historii Danii, w którym ona podobnie jak w ostatnich latach Polska - mierzyła się z wyzwaniami związanymi z przejściem od mniej czy bardziej autorytarnego systemu do demokracji i gospodarki wolnorynkowej, wówczas widzę wyraźnie, że to właśnie nowy typ wiedzy oraz kompleksowe informacje o uwarunkowaniach społecznych i ekonomiczno-gospodarczych były tymi czynnikami, które zadecydowały o sukcesie duńskiej transformacji. Dotyczyło to w szczególności umiejętności 
właściwego wykorzystania przez obywateli tej wolności, którą przyniosła za sobą nowa forma ustrojowa, a także wykorzystania związanych z nią nowych możliwości budowania sobie lepszego życia (Arch-KUL, 2003).

W Królestwie Danii, jak wiadomo, wielką rolę w realizacji wskazanych wyżej zadań odegrały tamtejsze uniwersytety ludowe. Ægidius mówił o tym w następujący sposób:

Pojawia się pytanie: skąd wówczas duńska ludność wiejska otrzymała ową nową wiedzę i informacje? W decydującej mierze - z tych wszystkich wyższych szkół ludowych [uniwersytetów ludowych - autorzy], które zostały z własnej inicjatywy lokalnych społeczności utworzone na obszarze całej Danii. Tam poprzez rozmowy, dyskusje i naukę mieszkańcy wsi dowiadywali się więcej o sobie, stosunkach społecznych, kulturze, ekonomii i gospodarce oraz nowych technologiach.

Ważnym elementem działalności wyższych szkół ludowych stał się również duch wiary w znaczenie wkładu jednostki w rozwój własny i własnej społeczności. Duch ten przenikał stosunki we wszystkich tych placówkach oświatowych, dając pojedynczemu słuchaczowi wiarę w siebie i siłę do takich działań, które pozwalały mu na przełożenie tego, czego od strony teoretycznej nauczył się w wyższej szkole ludowej, na praktykę funkcjonowania w życiu codziennym w rodzinie i społeczności wiejskiej, z których pochodził (Arch-KUL, 2003).

Podkreślił również, że to właśnie dzięki absolwentom duńskich uniwersytetów ludowych „po wsiach powstawały wówczas również liczne stowarzyszenia kulturalno-oświatowe i społeczne, które bazowały na demokratycznych zasadach” (Arch-KUL, 2003), a tym samym „uczyły” demokracji mieszkańców tamtejszych środowisk wiejskich.

Warta przywołania jest jeszcze jedna refleksja KUL-owskiego mentora:

Mam świadomość, że zwykli mieszkańcy polskiej wsi nie ponoszą odpowiedzialności za istniejące niesprzyjające warunki. Jednak to oni sami muszą wydostać się z nieszczęśliwej sytuacji samodzielnie. Niestety od nikogo innego nie można oczekiwać przejęcia odpowiedzialności za nieszczęścia „wielkiej” historii i „wielkiej” polityki. Pozostawanie w pasywnej roli ofiary to naturalna ludzka reakcja obronna. Niemniej jednak bardziej wartościowe, godne szacunku i skuteczne będzie aktywne przejęcie odpowiedzialności za losy i przyszłość swoją i swojego kraju (Arch-KUL, 2003).

Istotne są także - przygotowane kilka lat wcześniej, ale aktualne i w początkach bieżącego stulecia - propozycje ułożenia zakresu treści programowych Kaszubskiego Uniwersytetu Ludowego: 
- cel kursu powinien zostać zdefiniowany jako danie indywidualnemu słuchaczowi podstaw odpowiedzialności demokratycznej oraz kreowanie aktywnej postawy w podejmowaniu obowiązków społecznych;

- program edukacji tego typu można zdefiniować jako połączenie treści „pośrednich i bezpośrednich”: wiedzy praktycznie użytecznej i dającej zdolności do inicjowania wszelkich rodzajów związków kulturalnych, społecznych, ekologicznych i im podobnych twórczych wspólnot (Ægidius, 1992).

Wszystkie przypomniane wyżej opinie Ægidiusa wydawały się w środowisku KUL-u tym bardziej wartościowe i interesujące, że można było dostrzec czytelne analogie między wyzwaniami, przed którymi kiedyś stawała Dania, a aktualną sytuacją w Polsce. Nie powinno więc budzić zdziwienia, że zadania stające przed Kaszubskim Uniwersytetem Ludowym w XXI wieku sformułowano podobnie do zadań duńskich uniwersytetów sprzed lat. Jedyna wyraźniej dostrzegalna różnica polegała na uwypukleniu powinności związanych z pielęgnowaniem dziedzictwa kulturowego regionu Kaszub i Pomorza (por. np. Byczkowska, Byczkowski, Maliszewski, 2002, s. 44-64).

Konkludując ten wątek rozważań, można stwierdzić, że zarówno ideowe przesłanie, jak i sugestie programowo-metodyczne zawarte w refleksjach Ægidiusa stanowią do dzisiaj kanoniczne wręcz przesłanki do kształtowania kierunków pracy edukacyjno-wychowawczej w Kaszubskim Uniwersytecie Ludowym, pokazując jednocześnie ścisłe związki pomorskiej placówki ze skandynawskimi korzeniami UL-owskich idei.

\section{Wybrane aspekty funkcjonowania placówki w latach 2001-2017}

Czas przejść do doświadczeń Kaszubskiego Uniwersytetu Ludowego zdobytych w okresie XXI wieku. Niewątpliwie należałoby wskazać, w jaki sposób pomorski KUL z Wieżycy, czerpiąc ze skandynawskich tradycji, a jednocześnie wpisując się w polskie tradycje oświaty niezależnej, odnalazł swoje miejsce w ostatnich dwóch dekadach. Taki bilans warto wykonać w szczególności dla lat 2001-2017, gdyż z dniem 1 stycznia 2018 roku dokonała się w funkcjonowaniu kaszubskiego UL-u ważna zmiana personalna, związana z przejściem na emeryturę jednego z autorów niniejszego szkicu, a zarazem jego twórcy i wieloletniego dyrektora/prezesa zarządu*.

* Od powstania Kaszubskiego Uniwersytetu Ludowego do końca roku 2017 kierował nim Marek Byczkowski. Gdy przeszedł on na emeryturę, zamknięty został ponad 35-letni okres w historii placówki związany z jego działalnością. 


\section{Zmiana formuły organizacyjno-prawnej placówki}

Niewątpliwie jednym z ważniejszych wydarzeń w historii kaszubskiego UL-u w bieżącym stuleciu była zmiana formuły prawnej placówki. Po wielu dyskusjach i konsultacjach w gronie instytucji prowadzącej KUL, tj. Rady Naczelnej i Zarządu Głównego Zrzeszenia Kaszubsko-Pomorskiego, 21 lutego 2004 roku podjęto uchwałę o usamodzielnieniu uniwersytetu poprzez powołanie nowego podmiotu prawnego - fundacji o nazwie Kaszubski Uniwersytet Ludowy. Formalna sądowa rejestracja fundacji odbyła się w tym samym roku*.

Od tego momentu pieczę nad działalnością KUL-u sprawuje powoływana przez Zrzeszenie Kaszubsko-Pomorskie na trzyletnie kadencje Rada Fundacji Kaszubskiego Uniwersytetu Ludowego (której przewodniczył początkowo prof. Brunon Synak, a obecnie - prof. Cezary Obracht-Pondzyński). Za funkcjonowanie kaszubskiego UL-u odpowiada zaś Zarząd Fundacji (w którym funkcję prezesa zarządu sprawował do grudnia 2017 roku Marek Byczkowski, a następnie objął ją Mariusz Mówka). W tej nowej formule prawno-organizacyjnej Kaszubski Uniwersytet Ludowy funkcjonuje do dziś.

\section{Wybrane kierunki działalności z lat 2001-2017}

\section{Edukacja obywatelska}

Wieżycka placówka od chwili swego powstania podejmowała wiele inicjatyw z zakresu edukacji obywatelskiej. Nie inaczej było również po roku 2000. Można nawet postawić tezę, że w związku z procesami akcesyjnymi Polski do Unii Europejskiej podjęto szereg dodatkowych przedsięwzięć w tym zakresie. Warto zilustrować te działania kilkoma przykładami.

Na krótko przed formalnym przystąpieniem kraju do struktur UE kaszubski UL zrealizował projekt pt. „Europejski przystanek do edukacji i informacji”. Umożliwił on około 5 tys. mieszkańców powiatu kartuskiego - w dużej części rolnikom - podjęcie optymalnych decyzji dotyczących dalszego rozwoju swojego gospodarstwa, zróżnicowania źródeł dochodu, jak również spopularyzował wiedzę o procesach dostosowujących polskie rolnictwo do wymogów unijnych. Stało się to możliwe dzięki następującym działaniom:

\footnotetext{
* Wszystkie informacje zawarte w trzeciej części artykułu - o ile nie odnotowano inaczej - pochodzą z archiwum Kaszubskiego Uniwersytetu Ludowego (Arch-KUL, 2001-2017).
} 
- ustawieniu w wybranych miejscowościach powiatu 24 tablic informacyjnych pn. „Europejski przystanek do informacji” (po trzy tablice w każdej gminie powiatu);

- wydaniu informatora na temat Unii Europejskiej pt. „Przystanek do edukacji i informacji” (Borowski, Byczkowski, 2003; nakład 3250 egz.);

- przeprowadzeniu 24 spotkań informacyjnych i 16 edukacyjnych w tych wsiach, w których ustawiono tablice;

- przeprowadzeniu debaty pt. „Wieś kaszubska w procesie transformacji i integracji europejskiej, czyli o potrzebie wsparcia przeobrażeń w kontekście doświadczeń innych państw" z udziałem rolników, sołtysów, radnych rad gmin oraz gości z Danii, Litwy, Niemiec i Szwecji (11 września 2003 roku);

- zrealizowaniu - przy udziale pracowników naukowych i studentów Uniwersytetu Mikołaja Kopernika w Toruniu - badań na temat potrzeb edukacyjnych dorosłych mieszkańców wsi kaszubskiej (na przykładzie gminy Somonino);

- redagowaniu specjalistycznej rubryki informacyjnej w regionalnym wydaniu „Dziennika Bałtyckiego”.

Bezpośrednią kontynuacją wymienionych wyżej działań stało się utworzenie jesienią 2003 roku w siedzibie UL-u w Wieżycy Wiejskiego Centrum Informacji Europejskiej (w ramach współpracy z Programem AGRO-INFO), którego celem było dostarczanie rolnikom i pozostałym członkom społeczności wiejskiej informacji ułatwiających im przygotowanie swoich gospodarstw czy małych rodzinnych firm usługowych do akcesji Polski z UE (np. w zakresie praktycznej umiejętności wypełniania wniosków o dopłaty bezpośrednie).

Zasadniczym celem omówionych wyżej działań było przekazanie mieszkańcom wsi wiedzy i umiejętności, które z jednej strony znacząco ułatwią im odnalezienie się w nowej, unijnej rzeczywistości, z drugiej zaś - pozwolą im skorzystać z wielu różnych źródeł wsparcia i tym samym ułatwią osiągnięcie konkretnych korzyści ekonomicznych i modernizacyjnych.

Wydaje się więc, że KUL odegrał wówczas istotną rolę w przekazaniu społeczności lokalnej, w której funkcjonuje, rzetelnej wiedzy o zmieniających się zasadach gospodarowania $\mathrm{w}$ rolnictwie, dostosowywaniu gospodarstw rolnych do wymagań UE, możliwościach i metodach poszukiwania w gospodarstwach alternatywnych dochodów oraz o zasadach podejmowania działalności gospodarczej w sektorach pozarolniczych. 
Ten kierunek aktywności edukacyjnej kontynuowany był przez wieżycką placówkę jeszcze przez kilka lat po wejściu Polski do Unii Europejskiej i jest przykładem skutecznej odpowiedzi placówki na konkretne zapotrzebowanie edukacyjne, jakie pojawiło się w związku z konkretną sytuacją społeczno-polityczno-gospodarczą w określonym miejscu i czasie.

Dzięki staraniom KUL-u powołano również do życia i prowadzono przez kilka lat, cieszące się dużym zainteresowaniem, Punkty Poradnictwa Prawno-Obywatelskiego. Dyżurujący tam prawnicy służyli mieszkańcom powiatu kartuskiego wsparciem i nieodpłatną pomocą prawną w zakresie spraw mieszkaniowych i konsumenckich, świadczeń rodzinnych, ubezpieczeń społecznych, zatrudnienia i bezrobocia itp. Realizacja tej inicjatywy oprócz pomocy w konkretnych sprawach - przyczyniła się do podniesienia świadomości prawnej społeczności lokalnej.

Nieco na marginesie wątku rozważań odnoszącego się do edukacji obywatelskiej wspomnijmy, że jeszcze w końcu lat 90. ubiegłego stulecia Kaszubski Uniwersytet Ludowy rozpoczął działania na rzecz integracji całego środowiska polskich uniwersytetów ludowych jako placówek edukacji obywatelskiej społeczności wiejskich. W zamyśle poszczególne UL-e miałyby z jednej strony zachować swoją autonomię i niezależność, z drugiej zaś stworzyć platformę partnerskiej współpracy oraz możliwość wspólnego formułowania stanowiska wobec innych podmiotów (np. władz oświatowych). Działania te kontynuowano także w pierwszych latach XXI wieku (szczególnie mocno angażował się w nie twórca i lider KUL-u oraz wiceprzewodniczący jego ówczesnej Rady Programowej), choć wówczas jeszcze bez sukcesów (Byczkowski 2019, s. 67).

\section{Animacja społeczno-zawodowa osób dotkniętych lub zagrożonych marginalizacja}

Ważnym i niewątpliwie nowym kierunkiem, który pojawił się w działalności Kaszubskiego Uniwersytetu Ludowego w XXI wieku, stało się przeciwdziałanie marginalizacji społecznej mieszkańców regionu. Takie starania czynione były regularnie przez całe ostatnie 20-lecie. W tym zakresie podjęto w placówce szereg inicjatyw zmierzających do wsparcia różnych osób i środowisk dotkniętych wykluczeniem ze względu na: niski poziom kompetencji zawodowych, bezrobocie, starość, obniżenie dochodów w rodzinie (rolniczej) itp.

W poszukiwaniu nowych pomysłów na znalezienie zatrudnienia dla mieszkańców Kaszub i Pomorza już w 2004 roku zorganizowano seminarium nt. „Tradycje regionalne szansą w aktywizowaniu osób zagrożonych wykluczeniem społecznym". Dało ono podwaliny pod opracowanie założeń 
i programów różnorodnych przedsięwzięć, które zrealizowano w kolejnych latach. Oto przykłady:

- kurs podstawowy i cykl szkoleń dokształcających dla konsultantów ds. unijnego wsparcia, w którym wzięło udział kilkadziesiąt osób bezrobotnych z powiatów kartuskiego i kościerskiego;

- projekt „Wiedza i umiejętności - nowe szanse dla rodzin rolniczych", którego zadaniem było zachęcenie rolników mających trudności z utrzymaniem się z pracy w gospodarstwie do podejmowania dodatkowej, pozarolniczej działalności gospodarczej w sferze usług;

- projekt „Wsparcie przedsiębiorczych - czas na własną firmę”, który osobom z rodzin rolniczych dał z jednej strony motywację, z drugiej zaś fachowe przygotowanie do samodzielnej działalności gospodarczej, umożliwiając im jednocześnie skorzystanie z dotacji inwestycyjnej (w kwocie po 20 tys. zł każda);

- projekt „Smak Kaszubskiego Pierścienia - wanoga szlakiem gościńców kaszubskich"*, którego celem było uświadomienie uczestniczącym $\mathrm{w}$ nim bezrobotnym posiadającym podstawowe przygotowanie w zawodzie kucharza - kelnera możliwości i szans wynikających z wykorzystania elementów tradycji i kultury kuchni kaszubskiej w działalności gospodarczej;

- projekt „Kierowca bez kompleksów”, którego zadaniami było danie kilkudziesięciu osobom zagrożonym utratą pracy kwalifikacji kierowcy zawodowego, umiejętności porozumiewania się w języ$\mathrm{ku}$ angielskim oraz udzielania pierwszej pomocy - w połączeniu ze wzmocnieniem psychologicznym w zakresie aktywnego poszukiwania pracy, zarządzania swoim czasem oraz kształtowania poczucia sprawstwa;

- projekt „Wanoga od rolnictwa do turyzmu”, w którym uczestniczyło sto kilkadziesiąt osób - przedstawicieli rodzin z gospodarstw niskotowarowych, by zwiększyć szanse na (samo)zatrudnienie poza rolnictwem, szczególnie w sektorze rozrastającej się intensywnie na Kaszubach turystyki i agroturystyki oraz rekreacji (turystyki konnej, kuchni regionalnej, rękodzieła itp.).

Oceniając te działania, warto podkreślić, że to właśnie dzięki zastosowaniu klasycznych metod pracy edukacyjnej wypracowanych przez uniwer-

* Kaszubski Pierścień - umowna nazwa obszaru czterech powiatów: bytowskiego, kartuskiego, kościerskiego i lęborskiego. 
sytety ludowe udało się dotrzeć do wielu osób, które nie uzyskałyby podobnej szansy w placówkach edukacji formalnej.

\section{Edukacja regionalna, międzykulturowa, wielokulturowa}

Kolejnym ważnym obszarem w działalności Kaszubskiego Uniwersytetu Ludowego w omawianym okresie pozostawała, widoczna już wcześniej, w XX wieku, edukacja regionalna. Jest bowiem sprawą oczywistą, że instytucja kultury i edukacji pozaformalnej mająca w nazwie przymiotnik „kaszubski" będzie podejmowała zadania na rzecz swojego regionu. Zrealizowano więc w tym obszarze cały szereg zadań w związanych z językiem, tradycjami i kulturą kaszubską. Podejmowano jednak także projekty w zakresie edukacji i kultury innych regionów Pomorza (np. Kociewia czy Żuław), edukacji wielokulturowej i edukacji międzykulturowej.

Wiele z takich inicjatyw miało charakter cykliczny. Do najważniejszych przedsięwzięć na rzecz budowania tożsamości regionu można by zaliczyć Studium Wiedzy o Regionie dla Nauczycieli, różnorodne warsztaty realizowane w ramach programu „Modra Szkoła” (kaszubskiej obrzędowości dorocznej, garncarstwa kaszubskiego, plecionkarstwa, malarstwa na szkle, tkactwa ludowego i in.) czy organizowane od kilku dekad plenery twórców ludowych (rzeźba, malarstwo, haft $\mathrm{i}$ in.).

Za zadanie mające charakter cyklu należy niewątpliwie uznać również Pomorskie Forum Animatorów Kultury. Przed rokiem 2017 zrealizowano trzy jego edycje. W spotkaniach tych uczestniczyły osoby pracujące w samorządowych instytucjach kultury wszystkich szczebli - gminnego, powiatowego i wojewódzkiego, działacze organizacji społecznych oraz przedstawiciele środowisk naukowych zajmujących się zjawiskami kulturowymi. Głównym celem forum była każdorazowo wymiana informacji i doświadczeń, ale też wzajemne poznanie i integracja środowiska animatorów kultury.

Z kolei projekt „Edukacja dla Kaszub i Pomorza”, realizowany w ramach inicjatywy „Kształcenie ustawiczne dla rozwoju regionu”, skierowany był głównie do czynnych nauczycieli. Złożyły się nań cztery następujące moduły:

1. „Studium wiedzy o regionie” - moduł dający wiedzę merytoryczną, dotyczącą regionu, jak historia regionu, obrzędy i obyczaje regionalne, sztuka ludowa i rękodzieło, a także wybrane zagadnienia wielokulturowości Pomorza.

2. „Aktywne metody pracy grupowej” - moduł o charakterze metodycznym, dotyczący komunikacji interpersonalnej, aktywnego słuchania, 
możliwości wykorzystania gier szkoleniowych/dydaktycznych, sposobów aranżacji zajęć czy zagadnień ich ewaluacji.

3. „Kurs języka kaszubskiego” - moduł budujący podstawowe kompetencje w zakresie języka kaszubskiego, w którym kładziono nacisk na naukę czytania i rozumienia tekstów oraz praktyczną umiejętność pisania po kaszubsku.

4. „Podstawowy kurs obsługi komputera” - moduł uzupełniający kształtujący wśród uczestników umiejętność posługiwania się w codziennej pracy nauczycielskiej przydatnymi w szkole programami komputerowymi.

Projekt „Edukacja dla Kaszub i Pomorza” został w kolejnych latach kilkakrotnie powtórzony - w modyfikowanych wersjach programowych, uwzględniających oczekiwania jego głównych beneficjentów, tzn. nauczycieli. Wzięło w nim udział łącznie ponad 100 osób.

Co warte podkreślenia, przez cały omawiany okres w KUL-u w Wieżycy (a następnie w filii KUL-u w Starbieninie) funkcjonowała Galeria Współczesnej Sztuki Ludowej Kaszub i Kociewia, prezentująca w głównej mierze prace będące dorobkiem organizowanych rokrocznie Plenerów Twórców Ludowych i Malarzy Nieprofesjonalnych.

Kaszubski Uniwersytet Ludowy podjął też w latach 2001-2017 wiele inicjatyw w zakresie edukacji regionalnej, międzykulturowej i wielokulturowej, które nie miały charakteru cyklicznego. I je warto zilustrować kilkoma przykładami.

Jedną z ilustracji różnorodnej i często przez kaszubski UL podejmowanej współpracy ze środowiskami uczelni wyższych może być zrealizowany w 2003 roku projekt, w skład którego wchodziło seminarium „Wielokulturowość na tle przemian historycznych - przykład Pomorza”, połączone z warsztatami „Rok obrzędowy kaszubsko-pomorskiego pogranicza dawniej i dziś”. Uczestniczyła w nim kilkudziesięcioosobowa grupa studentów Uniwersytetu Mikołaja Kopernika w Toruniu, członków tamtejszego Studenckiego Koła Naukowego Pedagogów.

Z inicjatywy placówki naukowcy często podejmowali współpracę z regionalistami i animatorami kultury. Na przykład $z$ dużym zainteresowaniem w środowiskach naukowych i regionalnych spotkało się zorganizowane w filii w Starbieninie w końcu roku 2006 forum pt. „Dziedzictwo kaszubskiej kultury ludowej - problemy ochrony i upowszechniania". Tematy debaty ogniskowały się wokół takich problemów, jak:

- dziedzictwo i stan obecny kaszubskiej kultury ludowej;

- treść i realizacja zaleceń o ochronie dóbr kultury i naturalnego dziedzictwa; 
- określenie normatywu - kanonu kultury ludowej;

- koncepcje, metody i formy permanentnej edukacji w zakresie kultury;

- tworzenie platform współpracy instytucji i ludzi zaangażowanych w ochronę i upowszechnianie dóbr kultury ludowej (Byczkowski, 2020).

Konkluzje i rekomendacje tego spotkania są do dzisiaj uznawane za ważne i przywoływane w różnych środowiskach kaszubskich i pomorskich regionalistów oraz animatorów kultury.

Z kolei zrealizowany przez KUL w końcu pierwszej dekady XXI wieku projekt pt. „Pomorskie Forum Oświaty Dorosłych 2009 - edukacja regionalna a wielokulturowość Pomorza" można uznać za doskonałą ilustrację podejmowanych przez placówkę zadań, odnoszących się do problemów i wyzwań edukacji regionalnej w kontekście wielokulturowości Pomorza. W jego ramach przygotowano bowiem propozycje konkretnych inicjatyw i możliwych do realizacji przedsięwzięć, wynikających z wielokulturowości regionu. Ważnym celem tego projektu była również integracja środowiska liderów, edukatorów i animatorów oświaty i kultury regionalnej reprezentujących pomorskie mniejszości narodowe i etniczne. Sam projekt kontynuowano w kolejnych latach, ale dostosowywano go do specyfiki kulturowej wybranych subregionów Pomorza: Kaszub, Żuław, Powiśla, Kociewia itd.

\section{Wspótpraca międzynarodowa}

W wyniku poszukiwania możliwości rozszerzenia i zoptymalizowania działań KUL-u po roku 1990 placówka znacznie rozwinęła współpracę międzynarodową, by poprzez wymianę doświadczeń z bliźniaczymi podmiotami z zagranicy doskonalić własne programy i projekty oświatowe oraz koncepcje i metody pracy pedagogicznej.

Wydaje się, że kontakty zagraniczne KUL-u w pierwszych kilkunastu latach XXI stulecia osiągnęły swoje apogeum. Nawiązano partnerskie stosunki z wieloma instytucjami edukacji dorosłych w Skandynawii - głównie w Danii i w Szwecji, ale też w Finlandii, oraz w innych krajach: na Białorusi, w Bułgarii, w Estonii, w Finlandii, na Litwie, na Łotwie, w Niemczech, w Norwegii, w Rosji, w Szwajcarii, na Ukrainie i na Węgrzech. Przykłady wspólnych działań podejmowanych z podmiotami z innych krajów można by mnożyć. Był to bowiem w latach 2001-2017 niezwykle istotny obszar funkcjonowania KUL-u.

Szczególnie bliskie relacje łączyły kaszubski UL z duńskimi teoretykami i praktykami pozaformalnej edukacji dorosłych. Wśród najważniej- 
szych instytucji po stronie duńskiej, z którymi placówka współpracowała, można by wymienić wspomnianą już Wolną Szkołę Nauczycielską w Ollerup oraz Bornholmski Uniwersytet Ludowy (Bornholms Højskole). Ta pierwsza służyła wsparciem merytorycznym w zakresie idei „szkoły dla życia” i pedagogi(k)i grundtvigiańskiej - zwłaszcza za sprawą kilkukrotnie cytowanego już wcześniej w niniejszym szkicu prof. Karla Kristiana Ægidiusa. $\mathrm{Z}$ tym drugim wymieniano doświadczenia dotyczące metodyki pracy pedagogicznej w uniwersytecie ludowym i programów - zwłaszcza w czasach, gdy rektorem placówki był Karsten Thoborg (ale i później). Warto też wspomnieć o kontynuowaniu w początkach XXI wieku współpracy z duńskim Klubem Ekologicznym SFOF (nawiązanej w latach 90. XX wieku), czego efektem było powołanie do życia Ośrodka Edukacji Ekologicznej na bazie filii KUL-u w Starbieninie k. Choczewa.

Jeszcze liczniejsze kontakty Kaszubski Uniwersytet Ludowy utrzymywał ze środowiskiem szwedzkich uniwersytetów ludowych. Jedną z ważnych postaci współpracujących z placówką w początkach XXI wieku był prof. Hans Hovenberg z Uniwersytetu w Linköpingu (Maliszewski 2006). Dzięki jego wsparciu przez lata różnym polskim uniwersytetom ludowym - w tym kaszubskiemu UL-owi - udawało się nawiązywać współpracę z różnym partnerami edukacji pozaformalnej na terenie Szwecji*. Współpracowano też z poszczególnymi uniwersytetami ludowymi - w Albins, Alba, Kvarnby, Mora, Ränsäter, Skurup, Tollare oraz z katolickim St:a Maria folkhögskola w Malmö, z którym współdziałano przez kilkanaście lat (w okresie gdy jej rektorem był Stefan Bietkowski), co owocowało różnymi przedsięwzięciami po stronie szwedzkiej i polskiej, ale też wspólnymi szwedzko-polskimi działaniami podejmowanymi na Białorusi i Ukrainie.

Ważnym i stale widocznym kierunkiem współpracy zagranicznej KUL-u przez cały analizowany w tej części artykułu okres pozostawały Niemcy. Z jednej strony „konsumowano” kontakty nawiązane przez pomorską placówkę jeszcze w latach 90. XX wieku - realizowane wspólnie z internatowymi uniwersytetami ludowymi w Lubminie i Seddiner See (Heimvolkshochschule Lubmin i Heimvolkshochschule am Seddiner See), z drugiej zaś podjęto różnorodne nowe inicjatywy z innymi partnerami po stronie Niemiec. Na przykład wieloletnia współpraca z Krajowym Związkiem Kultury Meklemburgii-Pomorza Przedniego i z Kołem Przyjaciół Kaszub w Szweri-

* Ważnym podziękowaniem dla Hansa Hovenberga stało się zorganizowanie 14 września 2003 roku w Kaszubskim Uniwersytecie Ludowym obchodów 80 rocznicy urodzin tego szwedzkiego oświatowca, które skupiły liczne grono jego polskich i szwedzkich przyjaciół (por. Jach 2003, s. 188). 
nie zaowocowała takimi przedsięwzięciami, jak cykliczne „Dni Kaszubskie”, które organizowano w różnych miastach po stronie niemieckiej, wyjazdami studyjnymi mieszkańców Meklemburgii na Pomorze pod hasłami „szukamy własnych korzeni" i pokonywania wzajemnych polsko-niemieckich uprzedzeń. Inną ciekawą ilustracją działań na rzecz pojednania mogą być międzynarodowe obozy dla młodzieży starszej - jak np. niemiecko-polsko-duński obóz studyjny pod hasłem „Młodzież pogranicza - ślady znalezione, ślady odszukane" (lato 2003 roku).

Wiele działań podjęto też we współpracy merytorycznej z Instytutem Współpracy Międzynarodowej Niemieckiego Związku Uniwersytetów Powszechnych (IIZ/DVV) - zwłaszcza z dr. Norbertem F. B. Gregerem (ekspertem Instytutu) i prof. Ewą Przybylską (podówczas szefową biura IIZ/ /DVV w Warszawie, dzisiaj profesor zatrudnioną w Szkole Głównej Gospodarstwa Wiejskiego w Warszawie). Dzięki wsparciu finansowemu DVV Kaszubski Uniwersytet Ludowy mógł zrealizować również kilka szerzej zakreślonych projektów, w które były zaangażowane nie tylko podmioty z Polski i Niemiec, ale także $z$ innych krajów. Ilustracją takich przedsięwzięć mogą być działania KUL-u w ramach międzynarodowej grupy roboczej „Dostęp jakość - otwarcie. Edukacja dorosłych z obszarów wiejskich" (AQUA, 2004-2007). W składzie grupy znaleźli się wówczas edukatorzy dorosłych z krajów tzw. starej Europy oraz Europy Środkowo-Wschodniej (Armenia, Białoruś, Bułgaria, Dania, Litwa, Polska, Rosja, Niemcy - wschodnie landy, Rumunia, Słowacja i Węgry), a całość była finansowana przez przedstawicielstwo polskie IIZ/DVV.

Jak wspomniano wyżej, KUL podejmował współpracę z podmiotami oświaty i kultury także spoza Skandynawii i Niemiec. I tu przykłady można by mnożyć. W sposób bardziej trwały współpracowano przez ponad dekadę z oświatowcami z Ukrainy (2006-2017) - zwłaszcza z Zachodnio-Ukraińskim Centrum Zasobów (ZURC). W ramach tej współpracy, organizowanej albo w porozumieniu z partnerem szwedzkim (St:a Maria folkhögskola), albo ze środków rządu polskiego w ramach programu „Polska Pomoc MSZ”, zrealizowano szereg projektów, w ramach których KUL dzielił się z ukraińskimi partnerami swoimi doświadczeniami z okresu transformacji oraz propagował właściwe pozaformalnej edukacji dorosłych podejście metodyczne w pogłębianiu kompetencji obywatelskich społeczności lokalnych*.

* Na marginesie rozważań można przypomnieć, że chwilę wcześniej Kaszubski Uniwersytet Ludowy w partnerstwie z St:a Maria folkhögskola próbował podobne działania animacyjne podjąć na Białorusi. Niestety ten projekt zakończył się niepowodzeniem (por. ArchKUL 2003-2004, materiały projektu „Szkoła dla życia - kierunek Białoruś”). 
Podsumowując analizę kierunków współpracy międzynarodowej w latach 2001-2017, kiedy KUL-em kierował Marek Byczkowski, warto podkreślić, że była ona wielokierunkowa i wielowątkowa. Wśród zrealizowanych projektów znajdziemy i te małe, dwustronne, skupiające się na realizacji konkretnego wyzwania, i duże, wielonarodowe, w których Kaszubski Uniwersytet Ludowy bywał albo koordynatorem*, albo jednym z partnerów** Zdobyte $\mathrm{w}$ tym zakresie doświadczenia są niewątpliwie istotnym komponentem marki KUL i ważną częścią pamięci instytucjonalnej KUL-owskiego zespołu.

\section{Nowe rozwiqzania metodyczne}

Ważnym elementem pamięci instytucji, a więc i KUL-owskiej marki są rozwiązania metodyczne. W związku z ograniczonymi możliwościami finansowymi i czasowymi potencjalnych uczestników zajęć oraz brakiem ogólnokrajowych rozwiązań strukturalno-prawnych, dotyczących takich instytucji jak uniwersytety ludowe, wiele placówek jeszcze w początkach transformacji zmuszonych zostało do zawieszenia swego funkcjonowania. Te nieliczne, które przetrwały, chcąc nadal realizować zadania właściwe tradycjom grundtvigiańskim, musiały wypracować odmienną od tradycyjnej formułę organizacyjną i poszukać nowych, dostosowanych i do potrzeb, i do możliwości, rozwiązań metodycznych (Maliszewski 2015).

Warte uwypuklenia w czasie dokonywania bilansu dorobku Kaszubskiego Uniwersytetu Ludowego w pierwszych kilkunastu latach XXI wieku są zatem poszukiwania nowych, skutecznych metod pracy edukacyjno-wychowawczej. Prób podejmowano wiele - w zależności od charakteru danego zadania, które należało zrealizować, i grupy odbiorców danej oferty starając w sposób możliwie optymalny dostosowywać formułę metodyczną do potrzeb/sytuacji (Liedtke-Kątnik, 2017). Niektóre z rozwiązań metodycznych

* Umiejętność współpracy KUL-u z innymi partnerami pozwoliła np. na przeprowadzenie dużego, bo z udziałem aż 11 partnerów z czterech krajów, projektu pn. „Uniwersytet ludowy - szkoła dla życia” („Folk High School - School for Life”), którego głównym celem było znalezienie skutecznej koncepcji edukacji dorosłych dla osób ze środowisk defaworyzowanych, opartej na twórczym rozwinięciu tradycji uniwersytetów ludowych i grundtvigiańskiej idei „szkoły dla życia”. Projekt był dofinansowany grantem z Programu Komisji Europejskiej Socrates-Grundtvig i realizowano go w latach 2001-2004. Autorzy zrezygnowali z rozwijania tego wątku w niniejszym artykule, gdyż dokonania projektu były już omawiane na łamach „Rocznika Andragogicznego” w przeszłości (por. np. Kaszubski Uniwersytet Ludowy, 2002; Byczkowska, Maliszewski, 2003).Więcej na ten temat znajdzie Czytelnik również w publikacji: Byczkowski, Maliszewski, Przybylska (red., 2003.

** Por. np. Błaszczak, Maliszewski, Smuk-Stratenwerth (red.), 2017. 
przygotowanych w kaszubskim UL-u okazały się jednak dużo bardziej trwałe i dawno już wyszły poza fazę eksperymentu metodycznego.

Zwłaszcza dwie z wypracowanych przez grono pedagogiczne placówki innowacji metodycznych zasługują w tym miejscu na przywołanie. Są to:

1) metoda sąsiedzkich spotkań konsultacyjnych;

2) metoda wędrownego (wędrującego) uniwersytetu ludowego.

Pierwsza $z$ nich pojawiła się jeszcze w początkach bieżącego stulecia w związku z wyraźnie zauważalną potrzebą dotarcia z informacją na dany temat do osób zamieszkujących nawet najbardziej zaniedbane kulturowo i edukacyjnie małe społeczności wiejskie. Długo poszukiwano sposobów dotarcia do takich środowisk lokalnych - np. z wiedzą o zasadach gospodarowania na roli w ramach Unii Europejskiej, informacjami o możliwościach przeformułowania źródeł zarobkowania, zasadach podejmowania aktywności agroturystycznej czy różnych form edukacji obywatelskiej. W efekcie wypracowano formułę spotkań odbywanych bezpośrednio w danym środowisku lokalnym (często w prywatnych domach), w której KUL-owski konsultant - zakorzeniony w regionie jako „swój”, przekazywał informacje „swoim" odbiorcom. Ważnym aspektem tej metody okazała się po jakimś czasie także zauważalna multiplikacja efektów wśród sąsiadów tych osób, które w danym spotkaniu uczestniczyły.

Nieco odmiennym, ale również bardzo ważnym w działalności kaszubskiego UL-u rozwiązaniem metodycznym okazała się formuła uniwersytetu ludowego, który nie zaprasza na dany cykl edukacyjny do swojej siedziby, lecz rusza w teren. Bardzo dobrze założenia wędrownego UL-u definiują słowa jednego ze współautorów niniejszego szkicu:

Jeśli Ty nie możesz przyjechać do KUL-u - to KUL spakuje nauczycieli, materiały oraz sprzęt i przyjedzie do Ciebie. Załatw tylko lokum, może być biblioteka, szkoła, remiza, a może po prostu pokój w czyimś mieszkaniu (Byczkowski, 2020).

Nadmienić warto, że po fazie eksperymentowania w tym zakresie w pierwszej dekadzie stulecia, z czasem „Wędrowny Uniwersytet Ludowy” stał się ważną odrębną ofertą edukacyjną KUL-u, od lat cieszącą się ogromnym zainteresowaniem. Jej cele sformułowano następująco:

- pobudzenie społecznej aktywności mieszkańców wybranego sołectwa poprzez utworzenie lokalnego partnerstwa edukacyjnego;

- dostarczenie podstawowej wiedzy o stosunkach społecznych, kulturze, ekonomii i przyrodzie; 
- wzmacnianie kapitału społecznego opartego na zaufaniu, współuczestnictwie i współodpowiedzialności za podejmowane działania;

- rozwijanie kapitału ludzkiego poprzez rozbudzanie chęci rozwoju osobistego, podnoszenie kwalifikacji IT, kształtowanie nowych umiejętności zawodowych, np. w zakresie agroturystyki i różnych formach małej przedsiębiorczości.

$\mathrm{Z}$ poprowadzonych dotychczas $\mathrm{w}$ niniejszym szkicu analiz wyraźnie widać, że Kaszubski Uniwersytet Ludowy w latach 2001-2017 działał bardzo aktywnie i wielotorowo, potrafiąc odnaleźć się w nowej rzeczywistości społecznej i odnosząc „po drodze” wiele sukcesów edukacyjnych. W chwili przejmowania „sterów” placówki przez „nowego kapitana”, Mariusza Mówkę, co było związane z przejściem na emeryturę twórcy i wieloletniego lidera KUL-owskiego środowiska, Marka Byczkowskiego, następcę czekało niełatwe zadanie. KUL był już bowiem wówczas marką rozpoznawalną nie w tylko regionie kaszubsko-pomorskim, ale też na terenie całego kraju i poza jego granicami, a skumulowana pamięć instytucji obejmowała przebogate, gromadzone przez lata zasoby.

$\mathrm{Na}$ zakończenie tego wątku dodać warto, że na rok przez przejściem na emeryturę dotychczasowego prezesa zarządu KUL-u na nowo odżyły nadzieje na podniesienie rangi polskich uniwersytetów ludowych i uzyskanie rządowego wsparcia. W 2016 roku rozpoczęły się dyskusje nad planami ustanowienia centralnego programu wsparcia uniwersytetów ludowych. Wyraźny sygnał do rozpoczęcia prac nad programem dał wicepremier Piotr Gliński w czasie międzynarodowej konferencji poświęconej UL-om (współorganizowanej przez Kaszubski Uniwersytet Ludowy) w Europejskim Centrum Solidarności w Gdańsku 14 marca 2016 roku. To z kolei stało się impulsem do powołania do życia Ogólnopolskiego Stowarzyszenia Uniwersytetów Ludowych jako ciała reprezentującego środowisko polskich uniwersytetów ludowych względem podmiotów zewnętrznych, co nastąpiło kolejnego dnia w siedzibie KUL-u w Wieżycy (Felska 2016, s. 158-160). Tym samym realnych kształtów nabrała jedna z tych spraw, którym ustępujący ze stanowiska Prezesa Fundacji KUL Marek Byczkowski* poświęcił wiele energii w ostatnich kilkunastu latach kierowania wieżycką placówką.

* Wraz ze współpracownikami z KUL, a zwłaszcza z dr. T. Maliszewskim. 


\section{Kierunki rozwoju Kaszubskiego Uniwersytetu Ludowego po roku 2017}

Fundacja Kaszubskiego Uniwersytetu Ludowego jesienią 2017 roku podjęła decyzję o powierzeniu kierownictwa Kaszubskiego Uniwersytetu Ludowego* Mariuszowi Mówce - dotychczasowemu wieloletniemu współpracownikowi KUL-u w charakterze nauczyciela, wykładowcy i doradcy oraz - kilka miesięcy wcześniej - współautora raportu Uniwersytety ludowe. Identyfikacja kluczowych obszarów problemowych, celów i działań na przykładzie KUL w Wieżycy (Pawliszcze, Mówka, 2017)**. Objął on swoje stanowisko 1 grudnia 2017 roku, by do 1 stycznia 2018 roku przejąć wszystkie obowiązki Byczkowskiego (Internet 2).

\section{Raport Uniwersytety ludowe. Identyfikacja kluczowych obszarów problemowych, celów i dziatań}

Przygotowanie przez współpracowników Kaszubskiego Uniwersytetu Ludowego wspomnianego wyżej raportu zbiegło się w czasie z pracami na rzecz ustanowienia programu wsparcia uniwersytetów ludowych, a sama propozycja przeprowadzenia analizy i opracowania raportu miała służyć pomocą w odpowiedzi na pytania o cele wsparcia, które polskie UL-e miałyby otrzymać w ramach programu rządowego, oraz o spodziewane rezultaty (Arch-KUL 2017)***.

Nie wchodząc zbytnio w szczegóły raportu, przedstawmy jego konkluzje. Zdefiniowano w nim siedem kluczowych obszarów problemowych, które

* Formalnie zgodnie ze Statutem Rady Fundacji KUL - w charakterze Prezesa Zarządu Fundacji KUL (o kadencji trzyletniej) (Statut 2004, § 14).

** Skrót raportu dostępny jest również pod adresem internetowym: http://www. pracowniaswot.pl/wp-content/uploads/2016/10/raport_OSUL.pdf (Internet 1). W raporcie posłużono się autorską metodą analizowania danych. Jest ona oparta na klasycznej metodzie analizy SWOT, rozbudowanej o elementy rachunku macierzy oraz uzupełnionej innymi technikami analizy potencjału i otoczenia w kolejnych fazach generowania i redukcji danych. (por. też Kolupa, Nowakowski, 1990).

*** Pytania o cele programu wsparcia UL-ów bardzo mocno wybrzmiały na spotkaniu z dyrektorem Wojciechem Kaczmarczykiem z Kancelarii Prezesa Rady Ministrów z dnia 18 stycznia 2017 roku, które poświęcone było dyskusji nad wstępnymi założeniami przyszłego projektu. Prace nad gromadzeniem danych do raportu i ich analizą przeprowadzono w lutym i marcu 2017 roku w zespole roboczym złożonym z przedstawicieli Pracowni SWOT (Piotr Pawliszcze i Mariusz Mówka) przy wykorzystaniu wiedzy i doświadczenia ekspertów Kaszubskiego Uniwersytetu Ludowego w Wieżycy (Marek Byczkowski, Sulisława Borowska, Joanna Kreft, Monika Mielewczyk). 
stały się następnie jednym z punktów wyjścia do konstrukcji celów i wskazania oczekiwanych rezultatów w Założeniach do Rządowego Programu Rozwoju Uniwersytetów Ludowych. Oto one:

1. Uniwersytety ludowe nie są rozpoznawane wśród potencjalnych odbiorców jako demokratycznie urządzone placówki edukacji dorosłych („szkoły dla życia"), oferujące kształcenie w przyjaznym, niekonkurencyjnym środowisku uczenia się, w których stosowana jest grundtvigiańska metodyka pracy oparta na inicjatywie własnej i samopomocy uczestników.

2. Oferta dydaktyczna uniwersytetów ludowych w zakresie prowadzenia kursów pozwalających zdobywać kwalifikacje zawodowe oraz w zakresie prowadzenia procedur związanych $\mathrm{z}$ walidacją kompetencji zawodowych jest niedostateczna.

3. Uniwersytety ludowe dysponują ograniczoną bazą materialną i zasobami - w tym tymi, które są niezbędne dla edukacji wykorzystującej tradycyjne formy rękodzieła i sztuki ludowej.

4. Uniwersytety ludowe w ograniczonym stopniu wykorzystują i rozwijają metody pracy wyrastające z idei i wartości kultury ludowej (języka regionalnego) oraz szacunku dla innych kultur w budowaniu tożsamości lokalnych wspólnot.

5. Uniwersytety ludowe $\mathrm{w}$ niedostatecznym stopniu odpowiadają na rosnące potrzeby edukacyjne seniorów (60+) na wsi w zakresie edukacji w przyjaznym, niekonkurencyjnym środowisku uczenia się, szczególnie w kontekście zagrożeń związanych z wykluczeniem cyfrowym oraz zagrożeń dla jakości życia seniorów.

6. Uniwersytety ludowe $\mathrm{w}$ niedostatecznym stopniu adresują swoje działania edukacyjne do bezrobotnych młodych dorosłych (24-30) związane z rozwijaniem wśród nich postaw świadomego i aktywnego samorozwoju, opartych o wartości wolności, partnerstwa, inicjatywy, samopomocy oraz zrozumienia potrzeby działań na rzecz dobra wspólnego.

7. Uniwersytety ludowe w niedostatecznym stopniu wykorzystują możliwości, jakie niosą ze sobą nowe technologie/usługi społecznościowe/nowe media i towarzyszące im nowe formy kształcenia na odległość (blended learning, peer learning itp.) oraz nowe formy i kanały komunikowania się (Pawliszcze, Mówka, 2017).

Wyniki diagnozy przeprowadzonej na bazie doświadczeń Kaszubskiego Uniwersytetu Ludowego zostały uznane za reprezentatywne dla całego kraju i wykorzystane przy opracowaniu „Programu Wspierania Rozwoju Uniwersytetów Ludowych na lata 2020-2030” (Internet 3).

W raporcie Pracowni SWOT zdefiniowano także - wykorzystując KUL-owskie doświadczenia z działalności podejmowanej w XXI wieku - trzy 
kluczowe grupy potencjalnych odbiorców oferty uniwersytetów ludowych. Są nimi młodzi dorośli w wieku 24-30 lat pozostający bez pracy, seniorzy $(60+)$ oraz nauczycielki w przedziale wiekowym 40-60 lat. Te kategorie odbiorców oferty postanowiono zatem „zagospodarować" edukacyjne również w Kaszubskim Uniwersytecie Ludowym.

\section{Kierunki rozwoju KUL po roku 2017}

Zdefiniowane w omówionym wyżej raporcie obszary problemowe stały się podstawą określenia strategicznych kierunków rozwoju Kaszubskiego Uniwersytetu Ludowego na lata 2017-2020 również dla nowego Zarządu Fundacji KUL. Zostały one później rozwinięte przy okazji aplikowania o wsparcie finansowe do Narodowego Instytutu Wolności w ramach Programu Rozwoju Organizacji Obywatelskich (PROO).

Między innymi dzięki środkom uzyskanym z PROO Kaszubski Uniwersytet Ludowy realizuje dzisiaj swoją misję - w oparciu o plan działań przyjęty na okres do roku 2021. W tym dokumencie strukturę celów i działań oparto na diagnozie sytuacji KUL-u w zakresie realizacji celów statutowych oraz w zakresie rozwoju instytucjonalnego. Wyłoniono tym samym dwa kluczowe obszary problemowe istotne dla dalszego rozwoju placówki w latach 2018-2021 (i w okresie późniejszym) oraz związane z nimi wyzwania, co ukazano w poniższej tabeli.

\begin{tabular}{|c|l|}
\hline Obszar problemowy & \multicolumn{1}{c|}{ Diagnoza wyzwań } \\
\hline Działalność statutowa & $\begin{array}{l}\text { Nasi kluczowi interesariusze (młodzież, seniorzy, nauczyciele) nie rozpoznają } \\
\text { KUL-u i jego misji lub nie traktują jej jak własnej/dla siebie. (Czym jest uniwersytet } \\
\text { ludowy? Co to znaczy, że „ludowy”? Co znaczy, że „kaszubski”? A co, jeśli nie } \\
\text { jestem Kaszubka/Kaszubem? Co oni robią w KUL-u? Co mogłabym/mógłbym } \\
\text { robić wspólnie z nimi?) }\end{array}$ \\
\hline Rozwój instytucjonalny & $\begin{array}{l}\text { Brak środków finansowych na zakup mobilnych pracowni komputerowych działa- } \\
\text { jących w sieci, na poprawe warunków materialnych obiektów w Wieżycy oraz na } \\
\text { wzmocnienie personalne i rozwój kompetencji zespołu kaszubskiego UL-u. }\end{array}$ \\
\hline
\end{tabular}

W środowisku placówki sformułowano także ambitną wizję rozwoju Kaszubskiego Uniwersytetu Ludowego w okresie po roku 2021. Brzmi ona następująco: 
KUL jest zdolny do dalszego rozwoju. Dociera z ofertą i jest rozpoznawany przez kluczowych interesariuszy jako Wolny Uniwersytet Ludowy Kaszubów i Pomorzan, wykorzystując potencjał nowych technologii w zakresie form i metod pracy.

KUL oferuje słuchaczom lepsze zrozumienie siebie oraz swojej roli w lokalnej społeczności, a także daje możliwości wykorzystania dziedzictwa kultury i języka Kaszub dla aktywizacji i rozwoju lokalnych wspólnot i sieci współpracy opartych na dialogu (Mówka 2020).

Realizowany przez zespół pracowników i współpracowników KUL plan działań otrzymał wymowny tytuł: „W drodze i w cyfrowej chmurze”. Nie tylko oddaje on charakter przyszłych zamierzeń, ale pokazuje również na zebrane po roku 2017 doświadczenia z realizacji nowych, odmiennych niż wcześniejsze typów działań edukacyjnych, dla których pozyskano wsparcie publiczne*.

Niewątpliwie warto $\mathrm{w}$ tym miejscu wymienić przykładowe rodzaje działań i projekty, które stały się w latach 2018-2019 dla KUL-u „poligonem doświadczalnym” w testowaniu kolejnych nowych form, metod i narzędzi pracy z interesariuszami. Do najważniejszych należą:

- regranting;

- e-kompetencje interesariuszy;

- aktywizacja sąsiedztw.

Zostały one przedstawione w poniższej tabeli (choć biorąc pod uwage pewną syntetyczność i skrótowość opisu, tabela nie wyczerpuje list wszystkich działań podejmowanych przez KUL w tym okresie).

* Już po oddaniu artykułu do druku - w związku z pandemią koronawirusa COVID-19 i niemożliwością prowadzenia zajęć w kontakcie bezpośrednim ze słuchaczami - zespół kaszubskiego UL wiosną i latem 2020 roku rozbudował ofertę edukacyjną on-line, co znacząco przyspieszyło rozwój tego kierunku aktywności zawartego w opracowanym przez placówkę planie rozwoju (przyp. red.). 


\begin{tabular}{|c|c|c|}
\hline $\begin{array}{c}\text { Nowe formy i narzędzia pracy } \\
\text { z interesariuszami }\end{array}$ & Nazwa projektu & Program \\
\hline \multirow{3}{*}{$\begin{array}{l}\text { Regranting - mikrogranty dla } \\
\text { organizacji pozarządowych i grup } \\
\text { nieformalnych }\end{array}$} & $\begin{array}{l}\text { Uniwersytet Ludowy dla Kobiet Aktyw- } \\
\text { nych ULKA 2018-2019 }\end{array}$ & FIO 2018 \\
\hline & Senior ma głos! 2018 & ASOS 2018 \\
\hline & Wiejskie Kuźnie Pamięci 2019-2020 & MKiDN Edukacja kulturalna \\
\hline \multirow[b]{2}{*}{$\begin{array}{l}\text { Rozwijanie kompetencji seniorów } \\
\text { w zakresie komunikacji i współpra- } \\
\text { cy przy użyciu smartfonów }\end{array}$} & Senior ma głos! 2018 & ASOS 2018 \\
\hline & $\begin{array}{l}\text { NESTOR - standard wsparcia osób } \\
\text { starszych w powiecie kartuskim } \\
\text { Zajęcia w Klubach Seniora }\end{array}$ & \begin{tabular}{|l} 
Regionalny Program \\
Operacyjny Województwa \\
Pomorskiego na lata \\
2014-2020
\end{tabular} \\
\hline \multirow{3}{*}{$\begin{array}{l}\text { Aktywizacja sąsiedzka - między- } \\
\text { pokoleniowa i interdyscyplinarna } \\
\text { edukacja kulturalna jako sposób } \\
\text { oraz narzędzie aktywizacji i bu- } \\
\text { dzenie postaw zaangażowania } \\
\text { mieszkańców wsi }\end{array}$} & Walkuszowa Kuźnia Pamięci 2018 & EtnoPolska 2018 \\
\hline & $\begin{array}{l}\text { EtnoKGW. Nowocześnie o historii i oby- } \\
\text { czajach Kaszub }\end{array}$ & EtnoPolska 2019 \\
\hline & $\begin{array}{l}\text { Uniwersytet Ludowy dla Kobiet Aktyw- } \\
\text { nych ULKA 2018-2019 }\end{array}$ & FIO 2018 \\
\hline
\end{tabular}

Podsumowując realizowane przez KUL działania po 2017 roku, należy stwierdzić, że placówce udało się oprzeć swoją działalność na solidnej diagnozie strategicznej, z czym wiąże się podejmowanie decyzji dotyczących wyboru rodzajów i form działalności oraz - co za tym idzie - pozyskiwania środków publicznych na ich realizację w oparciu o czytelnie zdefiniowane cele strategiczne i jasno określone grupy interesariuszy.

Odnosząc się zaś do przemian, jakie zaszły w Kaszubskim Uniwersytecie Ludowym po 2017 roku, warto zwrócić uwagę, że dzięki pamięci instytucji i chęci utrzymania marki kontynuowano wiele kierunków działań wypracowanych w latach wcześniejszych. Zauważyć też można wyraźnie próby implementacji w pracę placówki wiele nowych, dotychczas niepojawiających się w niej elementów - zarówno w zakresie planowania i organizacji pracy, jak i w kwestiach programów i profilowania odbiorców przygotowywanych przez KUL propozycji edukacyjnych.

\section{Konkluzje}

Podsumowując rozważania dotyczące funkcjonowania Kaszubskiego Uniwersytetu Ludowego w XXI stuleciu, niewątpliwie warto zastanowić się, czy działająca w polskich realiach placówka pamięta jeszcze o głównych celach grundtvigiańskiego uniwersytetu ludowego, kryjących się pod takimi ha- 
słami jak: wolność, odpowiedzialność, demokracja, tolerancja, zaufanie czy współpraca. To właśnie kształtowanie tych wartości wśród odbiorów oferty programowej UL-ów wydawało się bowiem przez lata głównym zadaniem tych placówek. Po analizie działań KUL-u w obecnym stuleciu można stwierdzić, że mimo przemian wyraźnie nawiązuje on do skandynawskich pierwowzorów, skutecznie adaptując poszczególne elementy grundtvigiańskiej pedagogi(k)i do realiów swojego środowiska i czasów.

Niewątpliwie Kaszubski Uniwersytet Ludowy czeka jeszcze niejedna debata na ten temat. Niemniej w jego środowisku nie było dotychczas wątpliwości, że dla zachowania tożsamości placówki oraz dla skutecznego realizowania założonych celów konieczne wydaje się nieustanne powracanie do źródeł (Byczkowski 2020).

Oczywiście spojrzawszy w przeszłość, nie można nie dostrzec wyzwań, jakie niosą ze sobą nadchodzące czasy. Aby nie zostać uznany za swoisty edukacyjny skansen, Kaszubski Uniwersytet Ludowy musi więc śmiało wybiegać planami w przyszłość i próbować właściwie odczytywać nowe wyzwania, by je następnie skutecznie na nie odpowiedzieć za sprawą własnej oferty edukacyjnej.

To swoiste novum, które nastało w Kaszubskim Uniwersytecie Ludowym po 2017 roku, widoczne jest w opinii jednego ze współautorów artykułu, a zarazem osoby kierującej obecnie działalnością wieżyckiej placówki:

Pragnę zwrócić uwagę, na dwa kluczowe zagadnienia.

Po pierwsze - wracając do początku, ma znaczenie zachowania ciągłości pamięci instytucjonalnej KUL-u (wyrażającej się w rozwijaniu najlepszych pomysłów i metod zgromadzonych w organizacji) i podtrzymywaniu dobrej pamięci Odbiorców działań, które zmaterializowały się w postaci „Strategii rozwoju marki KUL”. Kolejne, nowe projekty KUL były poligonem, ale opartym na fundamencie „żywej” pamięci. Dzięki temu mogliśmy oferować takie formy działań, które owocują dzisiaj rozwijającą się siecią współpracy pomiędzy KUL-em a lokalnymi organizacjami i zamieszkującymi region ekspertami. Tym samym możemy myśleć o przyszłości KUL-u, jako organizacji parasolowej dla środowisk, grup nieformalnych, NGO-ów i samorządów lokalnych. Po drugie - wcześnie, bo w 2017 r., zdiagnozowaliśmy znaczenie edukacji zdalnej. Dzięki temu udało nam, począwszy już od końca 2018 r., zainicjować w KUL[-u] cztery procesy „cyfryzacji”:

1. „cyfryzacji” KUL[-u] - zasoby KUL[-u] dostępne on-line,

2. „cyfryzacji” Zespołu - rozwijanie kompetencji pracy zdalnej pracowników,

3. "cyfryzacji” metod uniwersytetu ludowego,

4. „cyfryzacji” interesariuszy - rozwijanie kompetencji interesariuszy. 
Wchodząc w czas cyfryzacji oferty edukacyjnej, otwieramy pole do dyskusji o relacjach i uwarunkowaniach zdalnego uczenia, które dałyby nową formę i narzędzia „tradycyjnym” procesom „samooświecenia” słuchaczy KUL-u, nie gubiąc przy tym fundamentalnych wartości procesu edukacyjnego: spotkania i dialogu (Mówka 2020).

Zatem, jak widać wyraźnie, w Kaszubskim Uniwersytecie Ludowym w ostatnich latach zaszły istotne zmiany. Czy wprowadzane sukcesywnie nowości stoją w opozycji do dotychczasowego dorobku placówki? Zapewne nie, co widać choćby w akcentowaniu i marki, i pamięci instytucji...

Przed wielu laty Stanisław Pestka wskazał, że

głównym celem wychowania Kaszubskiego Uniwersytetu Ludowego jest kształtowanie nowoczesnego, o szerokich horyzontach umysłowych człowieka określającego siebie poprzez życzliwy stosunek do innych. Człowieka „niezabłąkanego" w świecie polityki, gospodarki, kultury, lecz z powodzeniem podejmującego wyzwania, jakie niesie chwila obecna. Człowieka myślącego globalnie i działającego lokalnie (Pestka, 1989).

Można na zakończenie szkicu odpowiedzialnie stwierdzić, że myśl sformułowana przez tego wybitnego regionalistę kaszubskiego, poetę, redaktora i KUL-owskiego nauczyciela pozostawała aktualna przez cały okres funkcjonowania wieżyckiej placówki w bieżącym stuleciu. Podobnie będzie zapewne w nadchodzącej przyszłości. Gdyby bowiem w kaszubskim UL-u o tym zapomniano - po prostu przestałby on być uniwersytetem ludowym. Byłby to zmierzch kaszubsko-pomorskiej grundtvigiańskiej „szkoły dla życia”.

\section{Bibliografia}

Ægidius K. K. (1992), „List do Marka Byczkowskiego - dyrektora Kaszubskiego Uniwersytetu Ludowego w Wieżycy" (w zbiorach własnych adresata).

Arch-KUL (2001-2019), „Dokumentacja archiwalna Kaszubskiego Uniwersytetu Ludowego w Wieżycy za lata 2001-2019”.

Błaszczak I., Maliszewski T., Smuk-Stratenwerth E. (red.) (2017), Uniwersytety ludowe XX wieku. Tradycja - współczesność - wyzwania przyszłości, Stowarzyszenie Ekologiczno-Kulturalne „Ziarno”, Grzybów.

Borowska S., Maliszewski T. (2017), Przyszłość UL-owskiej idei na Pomorzu w świetle opinii absolwentów, wspótpracowników i partnerów Kaszubskiego Uniwersytetu Ludowego, [w:] I. Błaszczak, T. Maliszewski, E. Smuk-Stratenwerth (red.), Uniwersytety ludowe XX wieku. Tradycja - współczesność - wyzwania przyszłości, Stowarzyszenie Ekologiczno-Kulturalne „Ziarno”, Grzybów, s. 234-245. 
Borowska S. (2019), „ULKA - Uniwersytet Ludowy dla Kobiet Aktywnych” (dokument niepubl.), Wieżyca.

Borowski P., Byczkowski M. (red.) (2003), Przystanek do edukacji i informacji, Zrzeszenie Kaszubsko-Pomorskie, Gdańsk-Wieżyca.

Byczkowska S., Byczkowski M., Maliszewski T. (2002), Kaszubski Uniwersytet Ludowy u progu XXI wieku, „Oświatowiec”, nr 1(11), s. 44-64.

Byczkowski M. (2019), Uniwersytet ludowy w okresie transformacji ustrojowej-osiagnięcia i zaniechania. Głos na podstawie doświadczeń Kaszubskiego Uniwersytetu Ludowego, [w:] A. Felska (red.), Z ludźmi ku ludziom. Uniwersytety ludowe pomiędzy teoriq a praktyka, Zachodniopomorski Uniwersytet Ludowy - Fundacja, Mierzyn, s. 59-71.

Byczkowski M. (2020), „Kaszubski Uniwersytet Ludowy na początku XXI wieku osiągnięcia i zaniechania" (dokument niepubl.), Lębork.

Byczkowska S., Maliszewski T. (2003), Podsumowanie projektu Unii Europejskiej w ramach programu Socrates-Grundtvig „Uniwersytet ludowy - szkoła dla życia”, „Rocznik Andragogiczny”, s. 177-185.

Byczkowski M., Borowska S., Maliszewski T. (2017), Kaszubski Uniwersytet Ludowy jako szkoła dla życia - trójgłos zaangażowany(ch), [w:] I. Błaszczak, T. Maliszewski, E. Smuk-Stratenwerth (red.), Uniwersytety ludowe XX wieku. Tradycja - współczesność - wyzwania przyszłości, Stowarzyszenie Ekologiczno-Kulturalne „Ziarno”, Grzybów, s. 106-114.

Byczkowski M., Maliszewski T., Przybylska E. (red.) (2003), Uniwersytet ludowy szkoła dla życia, Kaszubski Uniwersytet Ludowy, Wieżyca.

Felska A. (2016), Kompetencje kluczowe - uniwersytety ludowe - społeczeństwo obywatelskie. W poszukiwaniu współczesnej „Szkoły dla życia” 14-15 marca 2016 r., Gdańsk - Wieżyca, „Edukacja Ustawiczna Dorosłych” nr 2(93), s. 158-160.

Jach D. (2003), Oświata dorosłych wobec wykluczenia społecznego: przeszłość - teraźniejszość - przyszłość, 12-14 września 2003 r., Gdańsk-Starbienino, „Rocznik Andragogiczny", s. 186-188.

Kapferer J.-N. (1995), Strategic Brand Management - New Approaches to Creating and Evaluating Brand Equity, Kogan Page Ltd, London.

Kolupa M., Nowakowski J. (1990), Wielokrotne macierze brzegowe i ich ekonometryczne zastosowania, PWN, Warszawa.

Liedtke-Kątnik B. (2017), Wybrane aspekty metodyki pracy Kaszubskiego Uniwersytetu Ludowego w świetle doświadczeń własnych nauczyciela, [w:] I. Błaszczak, T. Maliszewski, E. Smuk-Stratenwerth (red.), Uniwersytety ludowe XX wieku. Tradycja - współczesność - wyzwania przyszłości, Stowarzyszenie Ekologiczno-Kulturalne „Ziarno”, Grzybów, s. 128-132.

Kaszubski Uniwersytet Ludowy (2002), Projekt Unii Europejskiej „Uniwersytet ludowy - szkoła dla życia”, „Rocznik Andragogiczny”, s. 135-142.

Maliszewski T. (2006), Hans Hovenberg (1923-2006), „Edukacja Dorosłych”, nr 3(52), s. 157-160. 
Maliszewski T. (2015), Polski uniwersytet ludowy jako Szkoła dla Życia (1989-2014) ćwierćwiecze rozczarowań i nadziei, „Edukacja Dorosłych”, nr 1(72), s. 171-180.

Maliszewski T. (red.) (2016), Szkoła dla życia. Przewodnik po współczesnych uniwersytetach ludowych, Kaszubski Uniwersytet Ludowy, Stowarzyszenie Ekologiczno-Kulturalne „Ziarno”, Wieżyca-Grzybów.

Maliszewski T., Borowska S., Byczkowski M. (2018), Kaszubski Uniwersytet Ludowy w Wieżycy - kilka okolicznościowych impresji, [w:] A. Chabior (red.), Uczacy się dorosty - inspiracje, wyzwania, trendy. Księga Jubileuszowa poświęcona Profesorowi Tadeuszowi Aleksandrowi w 80. rocznicę urodzin i 55. rocznicę pracy zawodowej, Wydawnictwo WSBiP, Ostrowiec Świętokrzyski.

Mówka M. (2020), „Pamięć instytucjonalna i zmiana” (dokument niepubl.), Wieżyca. Pawliszcze P., Mówka M. (2017), Uniwersytety ludowe. Identyfikacja kluczowych obszarów problemowych, celów i działań na przykładzie KUL w Wieżycy, Pracownia SWOT, Gdynia-Gniewino.

Pestka S. (1989), Uniwersytet ludowy a region, „Ziemia Gdańska”, nr 153-154, s. $46-55$.

Serkowska A. (2019), „O plenerach sztuki ludowej i rękodzieła Kaszub, Pomorza” (dokument niepubl.), Wieżyca.

Statut (2004), Statut Fundacji Kaszubski Uniwersytet Ludowy (ustalony uchwałą Zarządu Głównego Zrzeszenia Kaszubsko-Pomorskiego z dnia 8 maja 2004 roku, z późn. zm.).

Szulc K. (2019), „Projekt Nestor - KUL-owskie Kluby Seniora” (dokument niepubl.), Paczewo.

\section{Netografia}

Internet 1 (2017), Uniwersytety ludowe Identyfikacja kluczowych obszarów problemowych, celów i działań na przykładzie KUL w Wieżycy. Wyciagg, http://www. pracowniaswot.pl/wp-content/uploads/2016/10/raport_OSUL.pdf (dostęp: 12.03.2020).

Internet 2 (2017), Wybrano Prezesa Zarządu Fundacji „Kaszubski Uniwersytet Ludowy”, https://kul.org.pl/wybrano-prezesa-zarzadu-fundacji-kaszubski-uniwersytetludowy/\# (dostęp: 28.02.2020).

Internet 3 (2020), Projekt programu wspierania rozwoju społeczeństwa obywatelskiego, pod nazwa „Program Wspierania Rozwoju Uniwersytetów Ludowych na lata 2020-2030”, Komitet ds. Pożytku Publicznego, https://www.gov.pl/web/pozytek/projektprogramu-wspierania-rozwoju-spoleczenstwa-obywatelskiego-pod-nazwaprogram-wspierania-rozwoju-uniwersytetow-ludowych-na-lata-2020-2030 (17.08.2020).

Internet 4 (2020), Program Rozwoju Organizacji Obywatelskich na lata 2018-2030 (PROO), https://www.niw.gov.pl/nasze-programy/proo-2/ (20.08.2020). 